\title{
Use of Vinasse and Sugarcane Bagasse for the Production of Enzymes by Lignocellulolytic Fungi
}

\author{
Mario Mamede Aguiar ${ }^{1 *}$, Luiz Fernando Romanholo Ferreira ${ }^{1}$ and Regina Teresa Rosim \\ Monteiro ${ }^{1}$ \\ ${ }^{l}$ Centro de Energia Nuclear na Agricultura; Laboratório de Ecologia Aplicada; Universidade de São Paulo; C. P.: \\ 96; Av. Centenário, 303; Piracicaba - SP - Brasil
}

\begin{abstract}
In this present work, three strains of Pleurotus and Trichoderma reesei were cultivated in media with pre-treated bagasse and vinasse. Cellulolytic and lignolytic activities and biomass production were analyzed. The treatment of the bagasse with $2 \% \mathrm{H}_{2} \mathrm{O}_{2}+1.5 \% \mathrm{NaOH}+$ autoclave resulted in a greater fiber breakage increasing the cellulose level up to 1.2 times and decreasing 8.5 times the hemicellulose content. This treatment also resulted in a high lignolytic activity for all cultures utilized. T. reesei produced laccase, peroxidase and manganese-peroxidase in all the treatments, having its manganese-peroxidase activity raging from 1.9 to 4.8 times higher than the basidiomycetes.
\end{abstract}

Key words Bagasse, Enzyme, Fungi, Lignocellulolytic, Pleurotus, Sugarcane

\section{INTRODUCTION}

The sugar-alcohol industry is an excellent representation of the developing process of Brazil, having sugarcane as one of the largest monocultures according to the Brazilian Service of Support for Micro and Small Companies (SEBRAE, 2008). The prediction for the sugarcane production for the 2008/2009 growing season is that the total amount will reach approximately 558.72 million tons, which will be processed in the sugar industry. This amount corresponds to an increase of $11.4 \%$ relating to the 2007/2008 growing season (CONAB, 2008). With this, there will also be an increase in the residues, among them, bagasse and vinasse. For each ton of sugarcane processed, approximately 250 to $280 \mathrm{~kg}$ of bagasse is produced; and between 700 and 900 liters of vinasse is obtained (CONAB, 2008). These residual products have the capacity to aggregate value to the final production depending in the sector in which are applied.

The biological degradation of the sugarcane bagasse involves the enzymatic hydrolysis of the glycosidic linkages from the cellulose chains and an attack on the lignin polymer. These cellulose fibers, in nature, are generally fixed with other polymers (Leshine, 1995; Melo and Azevedo, 1997), especially hemicellulose and pectin (Enari, 1983). The microorganisms capable of hydrolyzing these materials contain a complex system of a variety of enzymes. Such systems adhere to the cellular envelope and to the substrate, mediating a greater proximity necessary for the enzyme actions (Fengel and Wegener, 1989). Different microorganisms act in

*Author for correspondence: mamede.aguiar@gmail.com 
cooperation at several stages in the degradation of cellulose, releasing multiple compounds which are utilized in the metabolism (Melo and Azevedo, 1997; Esposito and Azevedo, 2004).

Lignin is a constituent of the cell wall of all the vascular plants, is a macromolecule consisting of units of phenylpropane, with a tridimensional and amorphous conformation, representing from 20 to $30 \%$ of the lignocellulosic material (Fagerstam et al., 1980). Due to the strict association between cellulose, hemicellulose and lignin, these compounds are not homogeneously distributed within the cell wall of the plant. The secondary wall contains high quality cellulose, while in the middle lamella, a higher quantity of lignin is found. However, all the three compounds can be found in all the layers of the cell wall.

The enzymes that constitute the multi-enzymatic lignocellulolytic include laccase (E.C. 1.10.3.2) (Kuhad et al. 1990; Kuwahara et al. 1984), lignin peroxidase (E.C. 1.11.1.14) (Kuhad et al. 1990) and manganese-peroxidase (E.C. 1.11.1.13) (Bon et al., 2008). These enzymes participate in the degradation of lignin. The enzymes responsible for the degradation of cellulose are exoglucanases (E.C. 3.2.1.91) (Kuwahara et al. 1984; Bon et al., 2008) and the endoglucanases (E.C. 3.2.1.4) (Bon et al., 2008).

The conversion of plant macromolecules into low molecular weight sugars that can be utilized directly or fermented may involve the following steps: reduction in the size of the material, pretreatment, enzymatic hydrolysis and simultaneous fermentation, and isolation of the reaction compounds. The pre-treatment allows a contact surface and a rupture in the structure of the lignin and cellulose fibers, consequently facilitating the hydrolysis to the simple sugar (Kuhad et al., 1990; Kuwahara et al,. 1984; Bon et al., 2008). The pretreatments can be physical (as defibrillation by pressure and explosion) or chemical (acid and alkaline hydrolysis).

The alkaline pre-treatment solubilizes the hemicellulose content. The physical-chemical pretreatments utilizing diluted acid and vapor pressure, allow the selective removal of the hemicellulose, producing sugar solutions with elevated pentose content and therefore reducing the lignin content. The alkali processes tend to promote a high dissolution of the lignin and lower the solubilization/fragmentation of the hemicelluloses (Melo and Azevedo, 1997; Enari,
1983; Esposito and Azevedo, 2004; Kuwahara et al. 1984; Bon et al., 2008).

The objective of this work was the selection of lignocellulolytic fungi and the evaluation of the enzyme production of these microorganisms, cultivated in chemically treated sugarcane bagasse with vinasse, under a range of temperatures, aiming towards the recovery of these residues for an eventual enzyme production.

\section{MATERIALS AND METHODS}

\section{Microorganisms}

The cultures of lignocellulolytic fungi were obtained from the Applied Ecology Laboratory, CENA-USP, Piracicaba, SP. The cultures were: Pleurotus sajor-caju CCB020, Pleurotus ostreatus, Pleurotus ostreatoroseus CCB440 and Trichoderma reesei.

\section{Bagasse substrate}

Sun-dried sugarcane bagasse donated by a local sugar-alcohol industry was collected. The shredded pieces were sieved at $1.19 \mathrm{~mm}$ (tyler14) to obtain smaller particles.

\section{Determination of cellulase and ligninase production}

The fungi were tested according to the capacity of producing cellulases and ligninases utilizing the methodology of Hankin and Anagnostakis (1975), with modifications in the media tested. For the production of ligninases, the medium contained $2.0 \mathrm{~g}$ sugarcane, $100 \mu \mathrm{L}$ guaiacol, $16 \mathrm{~g}$ agar and $1000 \mathrm{~mL}$ of distilled water. For cellulase production, the medium contained $10 \mathrm{~g}$ carboxymethyl cellulose (CMC), $10 \mathrm{~g}$ agar and $1000 \mathrm{~mL}$ of distilled water. Both, cellulase and ligninases media were autoclaved at $121^{\circ} \mathrm{C}$ for 15 minutes. In the medium containing cellulose (CMC), $10 \mathrm{~mL}$ of a Lugol-iodine solution was added to the Petri dish after growing the fungus for cellulase production.

The fungi were inoculated using $5.0 \mathrm{~mm}$ diameter disks from seven-days old cultures cultivated on malt-extract media. The Petri dishes were sealed and placed in an incubator at $28^{\circ} \mathrm{C}$ for seven days. The production of ligninases and cellulases were verified by the formation of a reddish growth halo in the guaiacol medium and a blue coloration in the medium with CMC. 


\section{Bagasse pre-treatment}

The bagasse was treated with $2 \% \mathrm{H}_{2} \mathrm{SO}_{4}, 1.5 \%$ $\mathrm{NaOH}, 2 \% \mathrm{H}_{2} \mathrm{O}_{2}$ and $2 \% \mathrm{H}_{2} \mathrm{O}_{2}+1.5 \% \mathrm{NaOH}$ in the proportion of $1: 10(\mathrm{w} / \mathrm{v})$ and autoclaved at $121^{\circ} \mathrm{C}$ for 15 minutes. The control consisted in non-treated bagasse added with distilled water + autoclave. After the treatment, all the samples were washed with distilled water in order to neutralize the effects of the reagents and dried at $60^{\circ} \mathrm{C}$ for $18 \mathrm{~h}$ and then analyzed for cellulose, hemicellulose and lignin as described by Goering and Van Soest, 1970.

\section{Vinasse characterization}

The vinasse was collected from the same local sugar-alcohol industry and was kept in sealed $5 \mathrm{~L}$ gallons and stored in cold room. Samples of this vinasse were characterized for its contents.

\section{Incubation and sampling}

The cellulase and ligninase producing cultures were transferred aseptically to $250 \mathrm{~mL}$ Erlenmeyer flasks containing $20 \mathrm{~g}$ bagasse with $60 \mathrm{~mL}$ of sterilized vinasse. The $\mathrm{pH}$ was adjusted to 6.0. The incubation was carried out in a controlled temperature incubator at $180 \mathrm{rpm}$ and 25, 30, 35 and $40^{\circ} \mathrm{C}$. The control consisted of $20 \mathrm{~g}$ bagasse and $60 \mathrm{~mL}$ minimal mineral medium $\left(\mathrm{g} \mathrm{L}^{-1}: 1.4\right.$ $\left(\mathrm{NH}_{4}\right)_{2} \mathrm{SO}_{4} ; \quad 2.0 \quad \mathrm{KH}_{2} \mathrm{PO}_{4} ; \quad 0.3 \quad$ urea, $\quad 0.3$ $\mathrm{MgSO}_{4} \cdot 7 \mathrm{H}_{2} \mathrm{O} ; \quad 0.0014 \quad \mathrm{ZnSO}_{4} \cdot 7 \mathrm{H}_{2} \mathrm{O} ; \quad 0.005$ $\mathrm{FeSO}_{4} \cdot 7 \mathrm{H}_{2} \mathrm{O} ; 0.0016 \mathrm{MnSO}_{4} ; 0.002 \mathrm{CoCl}_{2} ; 0.002$ $\mathrm{CaCl}_{2} ; 2.0 \mathrm{~mL}$ Tween-80 and $1.0 \mathrm{~mL}$ peptone). The experiment was carried out with three replicates during a period of 30 days. Every three days of incubation, a flask from each culture was vacuum filtered, using a Whatman $\mathrm{N}^{\mathrm{o}} 1$ filterpaper $(85 \mathrm{~mm} \emptyset)$. The supernatant was then transferred to a $50 \mathrm{~mL}$ Falcon tube for enzymes analysis.

The crude extract was frozen and lyophilized (Thermo Savant, model modulyod 115) for $72 \mathrm{~h}$ at $-48^{\circ} \mathrm{C}$ and 1.2 mbar, and the biomass was evaluated by gravity until a constant weight.

\section{Enzymatic analysis}

The activity of endoglucanase, exoglucanase, laccase, manganese-peroxidase and peroxidase were determined in triplicate by reading the absorbance by a FEMTO-432 spectrophotometer.

\section{Endoglucanase and exoglucanase activities}

The activity of endoglucanase (endo-1,4- $\beta$-Dglucanase) was determined by using carboxymethyl cellulose (CMC) as the substrate and the exoglucanase (exo-1,4- $\beta$-D-glucanase) by the dinitrosalycilic acid (DNS) technique, according to the methodology of Miller (1959). One unit (IU) of enzyme activity was defined as the amount required to release $1.0 \mu \mathrm{mol}$ of glucose from the appropriate substrates per minute per milliliter of crude filtrate under the assay conditions.

\section{Determination of laccase activity}

The activity of laccase was determined using a mixture containing $0.3 \mathrm{~mL}$ of a $0.05 \mathrm{M}$ citratephosphate buffer with $\mathrm{pH} 5.0 ; 0.1 \mathrm{~mL}$ solution of $0.05 \mathrm{~g}$ syringaldazine in $50 \mathrm{~mL}$ ethanol and 0.6 $\mathrm{mL}$ of the enzyme supernatant. The oxidation of syringaldazine was measured by monitoring the absorbance at $525 \mathrm{~nm}$ after 10 minutes of reaction. A unit of the enzymatic activity was defined as the quantity of the enzyme necessary to oxidize 1.0 $\mu$ mol of syringaldazine per minute, utilizing the molar extinction coefficient of $6.5 \times 10^{4} / \mathrm{mol} / \mathrm{cm}$ for oxidized syringaldazine. The laccase activity was expressed as international unit per liter (UI L ${ }^{-}$ ${ }^{1}$ ) of the extract (Szklar et al., 1989).

\section{Determination of manganese-peroxidase (MnP) activity}

The MnP activity from the crude enzyme extract was determined evaluating the oxidation of phenol red $\left(\epsilon_{610}=4460 \mathrm{~mol} \mathrm{~cm}{ }^{-1}\right)$ (Hankin and Anagnostakis, 1975) in the presence of manganese and $\mathrm{H}_{2} \mathrm{O}_{2}$ at $30^{\circ} \mathrm{C}$ in a mixture composed of $100 \mu \mathrm{L}$ of sodium-lactate buffer $\left(0.25 \mathrm{~mol} \mathrm{~L}^{-1}\right) ; 50 \mu \mathrm{L}$ of a $\mathrm{MnSO}_{4}\left(2.0 \mathrm{mmol} \mathrm{L}^{-1}\right)$ solution; $50 \mu \mathrm{L}$ of $\mathrm{H}_{2} \mathrm{O}_{2}$ in a sodium-succinate buffer $\left(0.2 \mathrm{~mol} \mathrm{~L}^{-1}\right)$ with $\mathrm{pH}$ of $4.5 ; 200 \mu \mathrm{L}$ bovine serum albumin $(0.5 \%)$ and $600 \mu \mathrm{L}$ of the crude enzyme extract. The reaction was initiated with the addition of $100 \mu \mathrm{L}$ phenol red $(0.1 \%)$ and the absorbance was measured at $610 \mathrm{~nm}$. To stop the reaction, $40 \mu \mathrm{L}$ of $2.0 \mathrm{~N} \mathrm{NaOH}$ was added after 10 minutes of the first reading. One unit of the enzyme activity was defined as the quantity of the enzyme necessary to form $1.0 \mu \mathrm{mol} \mathrm{de} \mathrm{Mn}^{+3}$ per minute, using the molar extinction coefficient of $4.460 \times 10^{3} / \mathrm{mol} / \mathrm{cm}$ (Hankin and Anagnostakis, 1975). The MnP activity was expressed as international unit per liter $\left(\mathrm{UI} \mathrm{L}^{-1}\right)$ of the extract.

\section{Determination of peroxidase activity}

The activity of peroxidase was performed according to the protocol established by Archibald 
(1992). Two 10 x $100 \mathrm{~mm}$ tubes were used, one for the non-boiled sample and the other for the boiled sample. In each tube, $0.6 \mathrm{~mL}$ of the sample to be analyzed was added with $0.2 \mathrm{~mL}$ of citratephosphate buffer and $0.1 \mathrm{~mL}$ of $\mathrm{H}_{2} \mathrm{O}_{2}$. One tube was put into boiling water for 10 minutes (control sample) and cooled for the analysis. The initial time was determined by the measure of the absorbance at the time at which $0.1 \mathrm{~mL}$ of syringaldazine was added. The final time was the measurement at 10 minutes after the reaction started. From each tube, $1.0 \mathrm{~mL}$ aliquots were taken from the boiled and non-boiled samples to measure against a blank at 460 nanometers. The peroxidase activity was expressed in international units per liter $\left(\mathrm{UI} \mathrm{L}^{-1}\right)$ of the extract.

\section{Statistical analysis}

The statistical tests were performed utilizing the statistical analysis software Assistat 7.5 by the Tukey's test with a significance level, $\mathrm{p}<0.05$ (5\%).

\section{RESULTS AND DISCUSSION}

Cellulase and ligninase production

A blue color halo was observed in the CMC-Lugol medium. The reddish color was due to the oxidation of guaiacol to tetraguaiacol (Hankin and Anagnostakis, 1975), which confirmed the lignolytic activity of the fungus, because the oxidation of guaiacol would occur only in the presence of peroxidase. The lugol reacts with some polysaccharides (Hankin and Anagnostakis, 1975). In the presence of starch, a blue color is formed due to the potassium iodide, rendering the elementary iodine soluble in water through the formation of the $\mathrm{I}_{3}{ }^{-}$ion in the helix formed by the amylase (Pereira, et al., 2003). The starch was produced by the degradation of the carboxymethyl cellulose in the medium into lower molecular weight saccharides, consequently confirming the presence of cellulases.

This experiment allowed the comparison of the capability of the fungi in producing cellulolytic and lignolytic enzymes and also demonstrated a promising method for selection of cultures for these enzymatic studies.

\section{Analysis of collected vinasse}

The temperatures at the time of the collection of vinasse varied from $95.5^{\circ} \mathrm{C}$ to $118^{\circ} \mathrm{C}$ and after cooling, the $\mathrm{pH}$ was between 3.95 and 4.5. The sample had high concentration of potassium and phosphorus and high values of COD and BOD as shown on Table 1.

Table 1 - Characterization of the vinasse in natura.

\begin{tabular}{lc}
\hline & Parameters of vinasse in natura \\
\hline $\mathrm{pH}\left(\right.$ at $\left.20^{\circ} \mathrm{C}\right)$ & 3,95 \\
$\mathrm{COD}\left(\mathrm{mg} \mathrm{L}^{-1}\right)$ & 42000 \\
$\mathrm{BOD}\left(\mathrm{mg} \mathrm{L}^{-1}\right)$ & 11310 \\
Total suspended solids $\left(\mathrm{mg} \mathrm{L}^{-1}\right)$ & 5969 \\
Total dissolved solids (ppm) & 152126 \\
Reducing sugars (mg L & 962 \\
Total Kjeldahl Nitrogen $\left(\mathrm{mg} \mathrm{L}^{-1}\right)$ & 70 \\
Potassium (mg L & 2272 \\
Phosphate (as P) $\left(\mathrm{mg} \mathrm{L}^{-1}\right)$ & 200 \\
\hline
\end{tabular}

\section{Analysis of the cellulose, hemicellulose and lignin content}

The treatments with the alkaline and acid solutions, with the exception of the $1.5 \% \mathrm{NaOH}$ resulted in increase in the level of cellulose in relation to the control, in the treatments with $2 \%$ $\mathrm{H}_{2} \mathrm{SO}_{4}$ and with $2 \% \mathrm{H}_{2} \mathrm{O}_{2}+1.5 \% \mathrm{NaOH}$, the cellulose levels were increased by 1.2 times (Table 2 ). These treatments promoted the rupture of the lignin and cellulose fibers found in the internal part of the bagasse fiber, being released or solubilized. The alteration in the level of hemicellulose occurs by the fact that the acidic treatments break the hemicellulose fibers, while the alkaline treatment solubilizes the hemicellulose, generating pentoses and hexoses such as xylose and arabinose in variable quantities (Mane et al., 2006; Fasanella, 2008; Doerge et al., 
1997). The bagasse treated with $2 \% \mathrm{H}_{2} \mathrm{O}_{2}+1.5 \%$ $\mathrm{NaOH}+$ autoclave at $121^{\circ} \mathrm{C}$ for 15 minutes was selected as it resulted high level of cellulose and lignin and decreased the level of hemicellulose However the high content of cellulose was obtained by the $2 \% \mathrm{H}_{2} \mathrm{SO}_{4}$ treatment, but this treatment was not chosen because the hemicellulose content was of $5.87 \%$, not facilitating the attack of the microbial enzymes in the free cellulose and lignin (Alborés et al., 2007). The remaining percentage as observed in Table 2 was due to other components such as proteins and lipids as stated by Goering and Van Soest, 1970.

\section{Mycelium quantification}

The quantity of the biomass produced after 30 days of cultivation in the mineral medium (Fig. 1) showed a significant variation among the cultures at $25^{\circ} \mathrm{C}$ in comparison to $30^{\circ} \mathrm{C}$, where the quantity of biomass produced by the fungi was much higher in $T$. reesei $\left(110.43 \mathrm{~g} \mathrm{~L}^{-1}\right)$; P. sajorcaju $\left(109.10 \mathrm{~g} \mathrm{~L}^{-1}\right)$; P. ostreatus $\left(103.62 \mathrm{~g} \mathrm{~L}^{-1}\right)$ and P. ostreatotoroseus $\left(88.67 \mathrm{~g} \mathrm{~L}^{-1}\right)$. At $35^{\circ} \mathrm{C}$ also a high biomass production was observed by $T$. reesei (105.49 $\left.\mathrm{g} \mathrm{L}^{-1}\right)$; P. sajor-caju $\left(101.78 \mathrm{~g} \mathrm{~L}^{-1}\right)$; P. ostreatotoroseus $\left(85.80 \mathrm{~g} \mathrm{~L}^{-1}\right)$ and P. ostreatus $\left(98.27 \mathrm{~g} \mathrm{~L}^{-1}\right)$. Figure 2 showed that the mycelial biomass had an increment in the medium containing sieved bagasse + vinasse, as compared to the mineral medium (Fig. 1). The most adequate temperature for a higher mycelial growth was between 30 and $35^{\circ} \mathrm{C}$. This range of temperature was expected since the microorganisms studied were mesophiles (Madan et al., 1983; Zhang, et al 2009). The fungal biomass at $30^{\circ} \mathrm{C}$ was $117.87 \mathrm{~g}$ $\mathrm{L}^{-1}$ for $P$. sajor-caju, $94.52 \mathrm{~g} \mathrm{~L}^{-1}$ for $P$. ostreatotoroseus, $112.31 \mathrm{~g} \mathrm{~L}^{-1}$ for P. ostreatus and $120.04 \mathrm{~g} \mathrm{~L}^{-1}$ for $T$. reesei. The relatively high production of biomass could be attributed to highly nutritious nature of the media utilized. The mineral medium contains the basic minerals while in the vinasse contains high values of nitrogen, potassium, phosphorus and organic matter; necessary elements in the composition of the cellular material (Esposito and Azevedo, 2004). The temperature of $30^{\circ} \mathrm{C}$ showed to be the most appropriate temperature for the production of biomass for the selected fungi.

Table 2 - Cellulose, lignin and hemicellulose levels of treated and un-treated sugarcane bagasse

\begin{tabular}{cccc}
\hline Treatment & Cellulose (\%) & Lignin (\%) & Hemicellulose (\%) \\
\hline Bagasse in natura (Control) & 55.34 & 11.21 & 25.87 \\
$2 \% \mathrm{H}_{2} \mathrm{SO}_{4}$ & 70.08 & 12.22 & 5.87 \\
$1.5 \% \mathrm{NaOH}$ & 53.44 & 9.75 & 11.98 \\
$2 \% \mathrm{H}_{2} \mathrm{O}_{2}$ & 59.50 & 13.37 & 8.46 \\
$2 \% \mathrm{H}_{2} \mathrm{O}_{2}+1.5 \% \mathrm{NaOH}$ & 67.31 & 15.87 & 2.98 \\
\hline
\end{tabular}

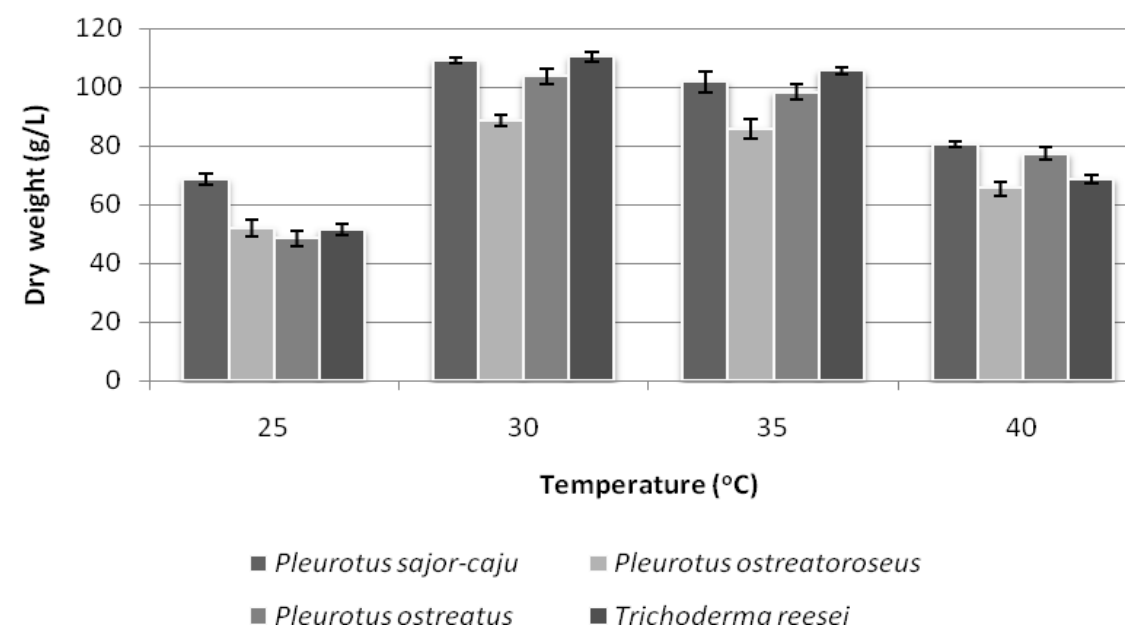

Figure 1 - Dry weight $\left(\mathrm{g} \mathrm{L}^{-1}\right)$ of selected fungi in relation to the temperature $\left({ }^{\circ} \mathrm{C}\right)$ cultivated in mineral (control) medium. 


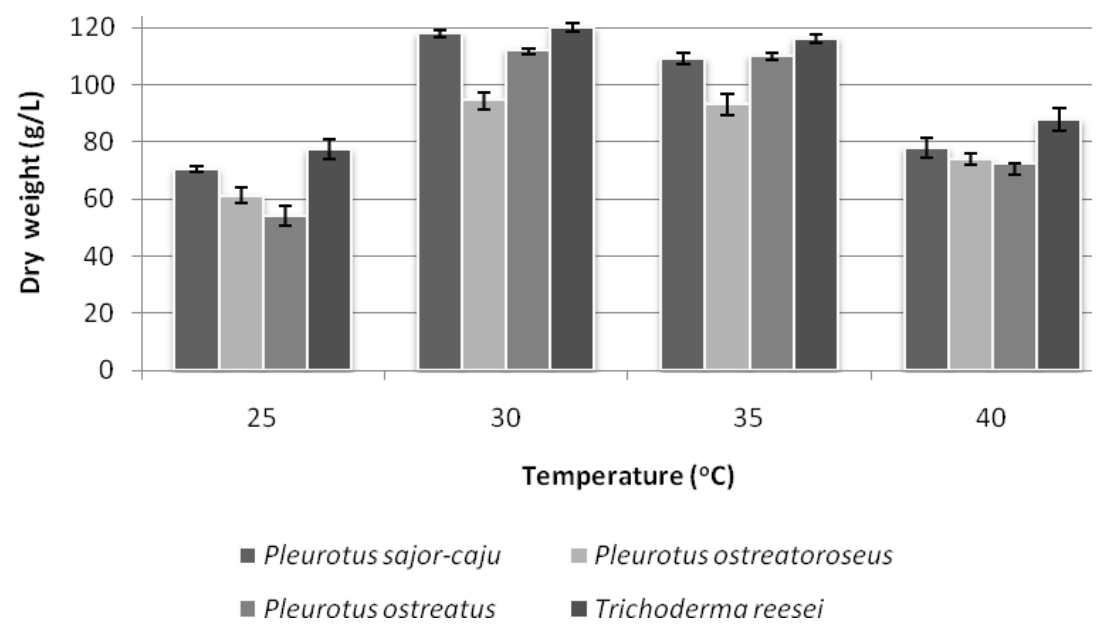

Figure 2 - Dry weight $\left(\mathrm{g} \mathrm{L}^{-1}\right)$ of selected fungi in relation to the temperature $\left({ }^{\circ} \mathrm{C}\right)$ cultivated in vinasse medium.

\section{Enzymatic activity analysis}

The Pleurotus showed a low enzymatic activity of exo- and endoglucanase (Fig. 3 and 4), while the $T$. reesei demonstrated endoglucanase activity (Fig. 4) with 3.23 and $5.88 \mathrm{U} \mathrm{mL}^{-1}$ at the $21^{\text {st }}$ and $24^{\text {th }}$ day of cultivation, respectively. T. reesei also showed a high exoglucanase activity (Fig. 3) with $18.35 \mathrm{U} \mathrm{mL}^{-1}$ at the $18^{\text {th }}$ day of growth.

The presence of endoglucanase may affect the activity of exoglucanase, since these microorganisms possess multiple distinct varieties of endo- and exoglucanases, acting together in a synergic manner.

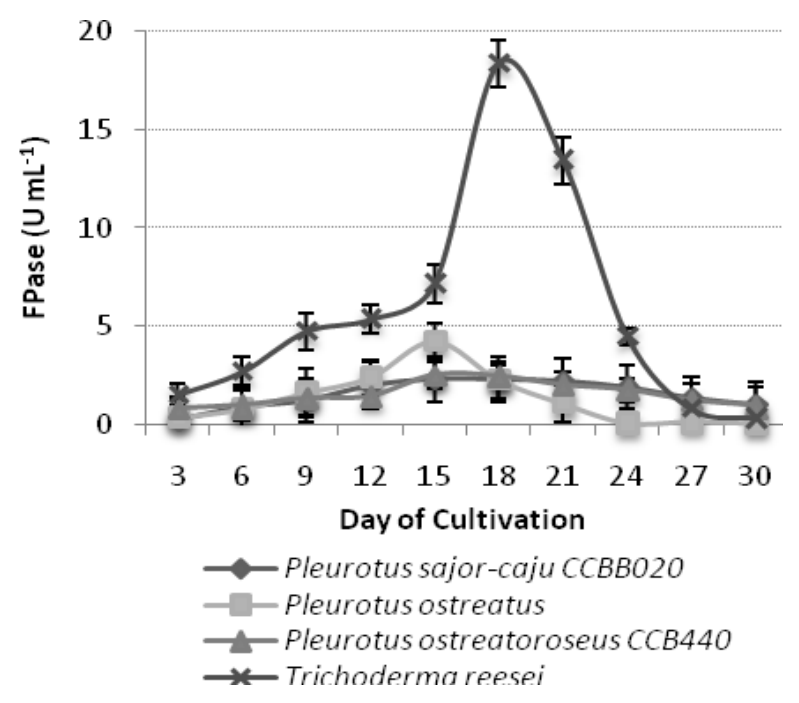

Figure 3 - Exoglucanase activity (FPase, $\mathrm{U} \mathrm{mL}^{-1}$ ) during 30 days of cultivation at $30^{\circ} \mathrm{C}$ cultivated in vinasse medium. 


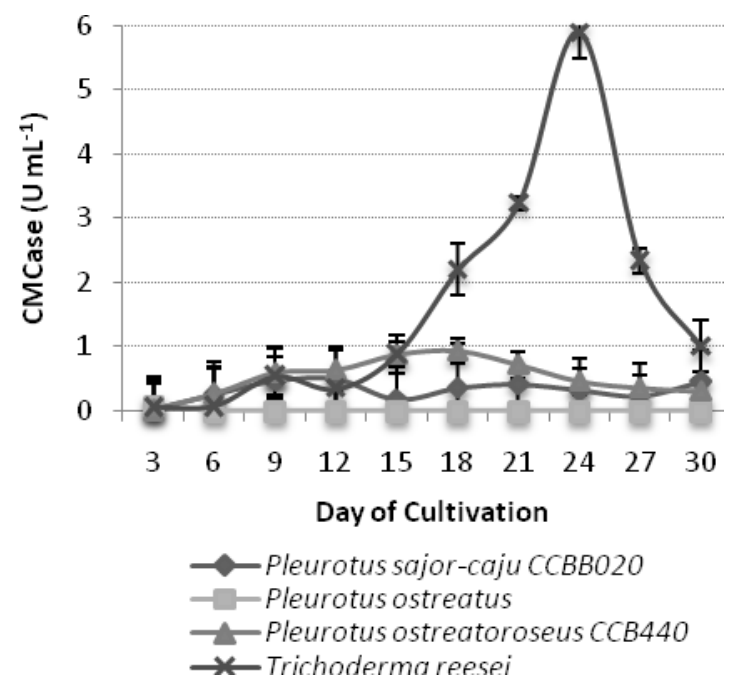

Figure 4 - Endoglucanase activity (CMCase, $\mathrm{U} \mathrm{mL}^{-1}$ ) during 30 days of cultivation at $30^{\circ} \mathrm{C}$ cultivated in vinasse medium.

Figure 5 shows the activity of laccase. P. sajorcaju at the first six days of cultivation showed $10.53 \mathrm{UI} \mathrm{L}^{-1}$, then decreased to $1.09 \mathrm{UI} \mathrm{L}^{-1} . P$. ostreatoroseus and $T$. reesei did not produce laccase. P. ostreatus produced 298.46 and 325.23 UI $\mathrm{L}^{-1}$. The $P$. sajor-caju showed high $\mathrm{MnP}$ activity starting at the sixth day of incubation, reaching a peak of $17.93 \mathrm{UI} \mathrm{L}^{-1}$ at the $12^{\text {th }}$ day of cultivation (Fig. 6). The activity for $P$. ostreatoroseus was undetectable for this enzyme. The activity of MnP for the P. ostreatus was high (27.69 $\left.\mathrm{UI} \mathrm{L}^{-1}\right)$ at the $21^{\text {st }}$ day of cultivation, while the $T$. reesei obtained a high manganeseperoxidase activity between the $15^{\text {th }}$ and $18^{\text {th }}$ day (19.02 and $18.08 \mathrm{UI} \mathrm{L}^{-1}$, respectively).

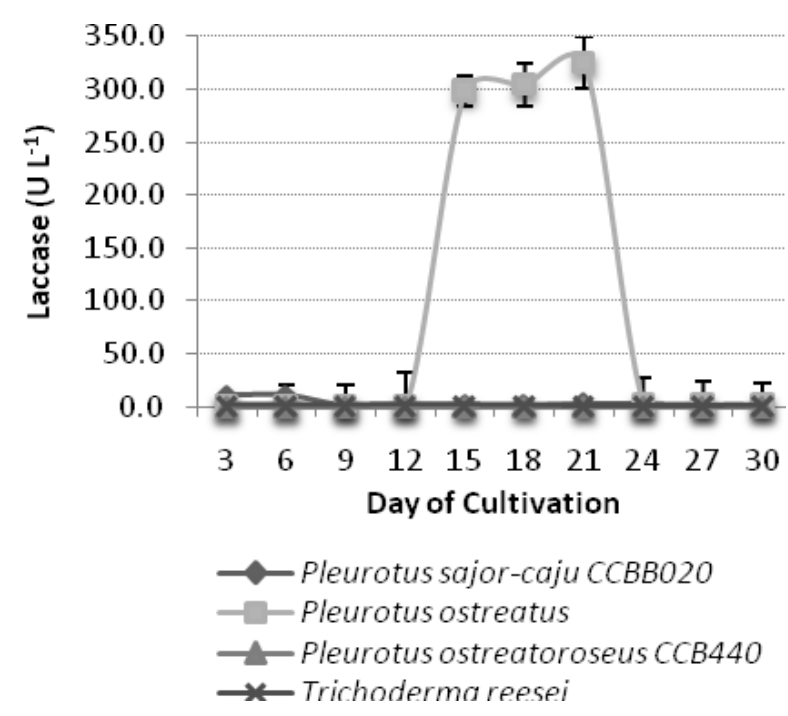

Figure 5 - Laccase activity (UI L ${ }^{-1}$ ) during 30 days of cultivation at $30^{\circ} \mathrm{C}$ cultivated in vinasse medium. 


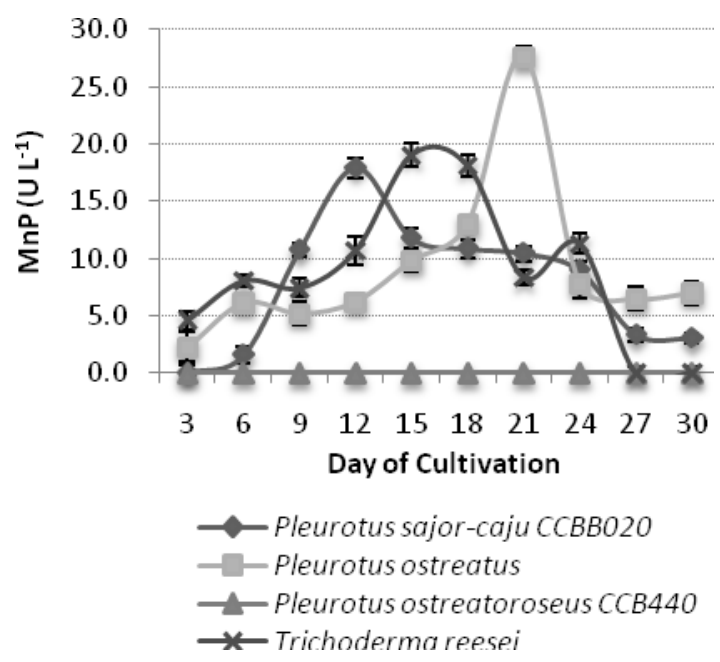

Figure 6 - Manganese-peroxidase activity (UI L ${ }^{-1}$ ) during 30 days of cultivation at $30^{\circ} \mathrm{C}$ cultivated in vinasse medium.

According to Hatakka (1994), since the decade of 1980s, manganese-peroxidases together with other peroxidases were discovered and certain groups of fungi were classified according to their enzymatic production capacity: those capable of producing $\mathrm{MnP}+$ peroxidases, $\mathrm{MnP}+$ laccases and those that produced peroxidases + laccases, however some exceptions were applied (Mane et al., 2006; Fasanella, 2008; Doerge et al., 1997; Flachner and Réczey, 2004). According to Figure 7, the peroxidase activity demonstrated by the $P$. sajorcaju was high at the first six days of incubation, and then decreased gradually. For P. ostreatus an activity of $19.84 \mathrm{UI} \mathrm{L}^{-1}$ was observed at the $15^{\text {th }}$ day, being the highest among the studied cultures. The $P$. ostreatoroseus did not show any activity of peroxidase, while $T$. reesei had a low activity of peroxidase, reaching $4.64 \mathrm{UI} \mathrm{L}^{-1}$ at the $21^{\text {st }}$ day of growth.

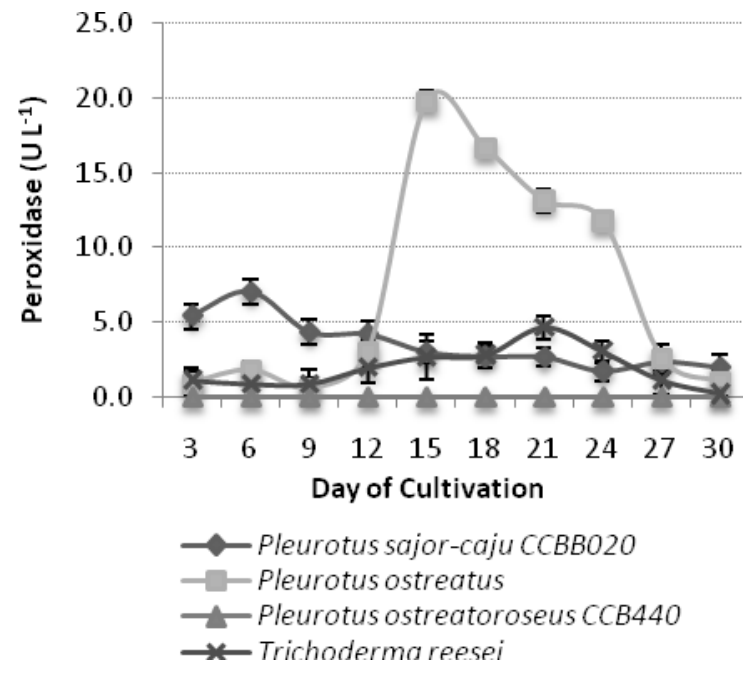

Figure 7 - Peroxidase activity (UI L ${ }^{-1}$ ) during 30 days of cultivation at $30^{\circ} \mathrm{C}$ cultivated in vinasse medium 


\section{CONCLUSION}

The P. sajor-caju CCB020, P. ostreatus and the $T$. reesei showed a higher mycelial biomass when cultivated in the medium containing vinasse, between 30 and $35^{\circ} \mathrm{C}$. The chemical pre-treatment of the bagasse which resulted in a better breakage of the fibers and the production of exoglucanases and endogluconases, was the treatment with $2 \%$ $\mathrm{H}_{2} \mathrm{O}_{2}+1.5 \% \mathrm{NaOH}+$ autoclave at $121^{\circ} \mathrm{C}$ for 15 minutes, making a better accessibility of the cultures to the fibers. The $T$. reesei had an oxidative activity of manganese-peroxidase when cultivated in medium containing bagasse and vinasse. It was concluded that the pre-treatment of the bagasse was an important parameter for increasing the cellulolytic and lignolytic enzyme production. The vinasse, in combination with bagasse, could be reused as a supplement to the production for these enzymes as well as the production of fungal biomass.

\section{RESUMO}

Recentemente o uso de material lignocelulolítico tem mostrado um importante avanço na produção de biocombustíveis. O bagaço e a vinhaça são resíduos oriundos do processamento da cana de açúcar e contem um alto teor de carbono, que geralmente é usado na co-geração de energia e ração animal. Três linhagens de Pleurotus e um ascomiceto, Trichoderma reesei, foram cultivados em bagaço pré-tratado e vinhaça. As atividades lignolíticas e celulolíticas foram analisadas, tanto quanto a produção de biomassa. Foi observado que o tratamento no bagaço com $2 \% \quad \mathrm{H}_{2} \mathrm{O}_{2}+1.5 \%$ $\mathrm{NaOH}+$ autoclave resultou numa maior quebra da fibra, aumentando o teor de celulose em 1.2 vezes mais e diminuiu em 8.5 vezes o conteúdo de hemicelulose. Este tratamento também resultou numa alta atividade lignolítica pelos fungos utilizados. $\mathrm{O}$ ascomiceto $T$. reesei produziu lacase, peroxidase e manganês-peroxidase em todos os tratamentos, tendo uma atividade de manganêsperoxidase variando entre 1.9 a 4.8 vezes mais que nos basidiomicetos.

\section{ACKNOWLEDGMENTS}

The authors thank the sugar-alcohol industry COSAN, for providing the bagasse and vinasse used in this study and the $\mathrm{CNPq}$ for funding this work and the Laboratory of Bromatology and Minerals of the Animal Science Institute at Nova Odessa, SP for providing the analyses of the material.

\section{REFERENCES}

Alborés, S.; Pianzolla, M.J; Soubes, M.; Cerdeiras, M.P. (2006), Biodegradation of agroindustrial wastes by Pleurotus spp for its use as ruminant feed. Electronic Journal of Biotech., 9, 3.

Archibald, F.S. (1992), A new assay for lignin-type peroxidases employing the dye azure B. Appl. Env. Microbiol., 58, 3110.

Bon, E.; Ferrara, M.; Corvo, M. (2008), Eds. In Enzimas em Biotecnologia - Produção, Aplicações $e$ Mercado. Interciência: Rio de Janeiro.

Companhia Nacional De Abastecimento - CONAB (2008), [homepage on the Internet]. Brasilia, DF. Available from: http://www.conab.gov.br.

Doerge, D.R.; Divi, R.L.; ChurchwelL, M.I. (1997), Identification of the colored guaiacol oxidation product produced by peroxidases. Anal. Biochem. 250, 10.

Enari, T. M. (1983), Microbial lipases. London: Applied Science Publishers.

Esposito, E.; Azevedo, J. L. Eds. (2004), Fungos decompositores de materiais lignocelulolíticos. Caxias do Sul, RS.

Fagerstam, L.G.; Pettesson L.G. (1980), The 1,4-hglucan cellobiohydrolases of Trichoderma reesei QM9414. FEMS Microbiol. Letters, 119.

Fasanella, C.C. (2008). Master of Science Dissertation, [homepage on the Internet]. Piracicaba, SP. Available from: http://www.teses.usp.br

Fengel, D.; Wegener, G. (1989), Wood chemistry, ultrastructure and reactions. New York: Walter de Gryuter.

Flachner, B.; Réczey, K. (2004), $\beta$-glucosidase production and characterization of some Aspergillus strains. Chem. Biochem. Engin. Quart., 18, 30.

Goering, H.K; Van Soest, P.J (1970), Forage fiber analysis (Apparatus, reagents, procedures and some applications). Washington: United Stated Department of Agriculture. 
Hankin, L.; Anagnostakis, S.L. (1975), The use of solid media for detection of enzyme production by (pathoenic and saprophytic) fungi. Mycol, 67.

Hatakka A. (1994), Lignin-modifying enzymes from selected white-rot fungi: production and role in lignin degradation. FEMS Microbiol. Lett. 13, 125.

Kuhad, R.C. (1990). Singh, A.; Eriksson, K.E.L. Microorganisms and enzymes involved in the degradation of plant fiber cell walls. Adv. Bioch. Biotech., 57, 45.

Kuwahara, M.; Glenn, J. K.; Morgan, M. A.; Gold, M. H. (1984), Separation and characterization of two extracellular $\mathrm{H}_{2} \mathrm{O}_{2}$ dependet oxidases from lignolytic cultures of Phanerochaete chrysosporium. FEMS Microbiol. Lett., 169.

Leschine, S. (1995), Cellulose degradation in anaerobic environments. Аnnu. Rev. Microbiol, 49: 399.

Madan, M.; Bisaria, R. C. (1983), ellulolytic enzymes from an edible mushroom Pleurotus sajor-caju. Biotech Letters., 5, 9

Mane, J.D.; Modi, S.; Nagawade, S.; Phadnis, S.P.; Bhandari, V.M. (2006), Treatment of spentwash using chemically modifed bagasse and colour removal studies. Bioresour. Technol., 97, 1752.
Melo, I.S.; Azevedo, J.L. Eds. (1997) Biodegradação de lignina e tratamento de efluentes por fungos lignolíticos. Jaguariúna, SP: CNPM/EMBRAPA.

Miller, G.L. (1959), Use of dinitrosalicylic acid reagent for determination of reducing sugar. Anal Chem., 31, 426.

Pereira Júnior, J.; Correia, M. J.; Oliveira, N. T. (2003), Cellulase activity of a Lentinula edodes (Berk.) Pegl. strain grown in media containing carboximetilcellulose or microcrystalline cellulose. Braz. arch. biol. technol., 46, 3 .

Serviço Brasileiro De Apoio A Micro E Pequenas Empresas - SEBRAE. (2008), [homepage on the Internet]. Brasilia, DF. Available from: http://www.sebrae.com.br/paginaInicial.

Szklar, G.; Antibus, R. K.; Sinsabaugh, R. L.; Linkins, A. (1989), Production of phenoloxidases and peroxidases by wood-rotting fungi. Mycol., 81, 234.

Zhang, Y.; Lu, X.; Dan, H.; Sun, Y. (2009). Screening and enzymatic study of a composite microbial system FH3. Braz. arch. biol. technol. 52, 1.
Received: April 15, 2009; Revised: August 11, 2009; Accepted: April 22, 2010. 